\title{
Taxonomical re-investigation of Sarmatian diatoms from NE Bulgaria, hosted in the Pantocsek Collection (Budapest)
}

\author{
Nadja Ognjanova-Rumenoval, Krisztina Buczkó2 \\ ${ }^{1}$ Geological Institute, Bulgarian Academy of Sciences, Acad. G. Bonchev Str., Bl. 24, 1113 Sofia, Bulgaria; \\ e-mail:nognjan@geology.bas.bg \\ ${ }^{2}$ Hungarian Natural History Museum, Department of Botany, 1476 Budapest, P.O. Box 222, Hungary \\ (Accepted in revised form December 2015)
}

\begin{abstract}
In the present paper, material collected from the vicinity of Balchik (NE Bulgaria) and housed in the Pantocsek Collection at the Hungarian Natural History Museum (Budapest) has been studied. Ten characteristic diatom species of regional and local importance were revised using scanning electron microscopy in order to clarify their identity. The purpose of the present paper is to elaborate on and photographically document the morphological variability of the examined taxa, and to compare the species composition with previously published data. The presence of Surirella comis Schmidt has been recognized for the first time from Bulgaria, as either fossil or recent form. Species characteristic for the association of the Achnathes baldjikii var. podolica Subzone have been indicated. Its stratigraphic range is within the Sarmatian Stage (Bessarabian Substage).
\end{abstract}

Ognjanova-Rumenova, N., Buczkó, K. 2015. Taxonomical re-investigation of Sarmatian diatoms from NE Bulgaria, hosted in the Pantocsek Collection (Budapest). Geologica Balcanica 44 (1-3), 39-50.

Key words: Diatoms, Sarmatian Stage (Bessarabian Substage), Balchik, Bulgaria, Pantocsek Collection, Budapest.

\section{INTRODUCTION}

The fossil diatom microflora from sediments in the area of the Town of Balchik, NE Bulgaria, has been the subject of previous investigations. These deposits have been known to the diatomists for about 150 years, and new fossil diatom species were established in the classical phycological works of Brightwell (1859), Grunow (1862, 1880, 1886), Schmidt (1874-1959), Cleve (1894, 1895), Pantocsek $(1892,1905)$. From this early period of investigations, fifty-four species and varieties of diatoms are known, among which a great number of new species named after Balchik (see Temniskova-Topalova, 1994). Hustedt (1927-1966) presented descriptions and critical notes on certain fossil diatom species from this area. Ross (1963) made the first revision of the fossil diatoms from Balchik, hosted in the Diatom Collection at the Natural History Museum (London), but he misinterpreted the age of the sediments as Pliocene.

During the last decades, many palaeoecological and stratigraphical studies have been carried out, based on synthesis of diatom assemblages from the Varna-
Balchik region (NE Bulgaria). Continuous sequences, from series of cores and outcrops, were studied by Temniskova-Topalova (1994). Temniskova-Topalova (1990) established local diatom biostratigraphic zones and correlated them with mollusk, foraminiferal and ostracod zones. The stratigraphic distribution of index taxa has been traced within the boundaries of the Eastern and the Central Paratethys (TemniskovaTopalova, 1982; Kozyrenko, Temniskova-Topalova, 1990; Olshtynskaya, 2001).

Several interesting species have been revised and new species belonging to the genera Amphora and Diploneis have been described (Temniskova-Topalova, EconomouAmilli, 1989; Droop, 1998; Levkov, 2009).

In the present paper, material collected from the vicinity of Balchik and housed in the Pantocsek Collection at the Hungarian Natural History Museum (Budapest) has been studied. Characteristic diatom species of regional and local importance were revised, e.g., Actinocyclus (?) podolicus (Missuna) Kozyrenko, Caloneis sectilis (A.S.) Cl. var. boryana (Pantocsek) Cleve, Campylodiscus limbatus var. astralis Eulenstein, Surirella baldjickii Norman, 
Podosira loczyi Pantocsek. The purpose of this investigation is to bring clarity and to document photographically the morphological variability of the studied taxa, as well as to compare the species composition with previous finds.

\section{MATERIAL AND METHODS}

The examined material consists of raw material from Neogene brackish-marine sediments near the Town of Balchik, NE Bulgaria, housed in the Pantocsek Diatom Collection at the Hungarian Natural History Museum (Budapest). The raw material was used for permanent slides (BP 2247-2251) and SEM stubs. We have no information about the cleaning and possible sieving method of Pantocsek. Permanent microscope diatom slides were mounted, using Zrax resin. Preparations were examined with scanning electron microscope (SEM); coating with gold-palladium was accomplished, using a XC7620 Mini Sputter Coater. A Hitachi S-2600N scanning electron microscope operated at $20 \mathrm{kV}$ and 5-8 mm distance was used.

The terminology used in this study principally follows that of Anonymous (1975), Ross et al. (1979) and
Round et al. (1990). The validity of the taxa was checked in Algaebase (Guiry, Guiry, 2016).

\section{GEOLOGY OF THE BALCHIK LOCALITY}

Neogene sediments in NE Bulgaria fill the shallow inland Bay of Varna-Balchik of the Euxinian Basin. Four structural and palaeogeographic regions were distinguished in NE Bulgaria by Kojumdgieva, Popov (1981): 1) Silistra-Ruse region (eastern end of the Dacian basin); 2) Southern Dobrudzha strait; 3) Border region of the Varna-Balchik depression; and 4) Varna-Balchik depression with two parts: Varna (south part) and Balchik (north part). Popov, Kojumdgieva (1987) introduced seven formal and two informal lithostratigraphic units for the Miocene of the area.

The diatom assemblages from the Varna-Balchik depression were identified in detail in the succession in different stratigraphic levels by Temniskova-Topalova (1994). Local diatom biostratigraphical zones were introduced by Temniskova-Topalova (1990). The investigated material was presumably collected from the diatomite deposits of the Evxinograd Formation, stratigraphic range: Bessarabian, Sarmatian s.1. (Fig. 1.1-6).
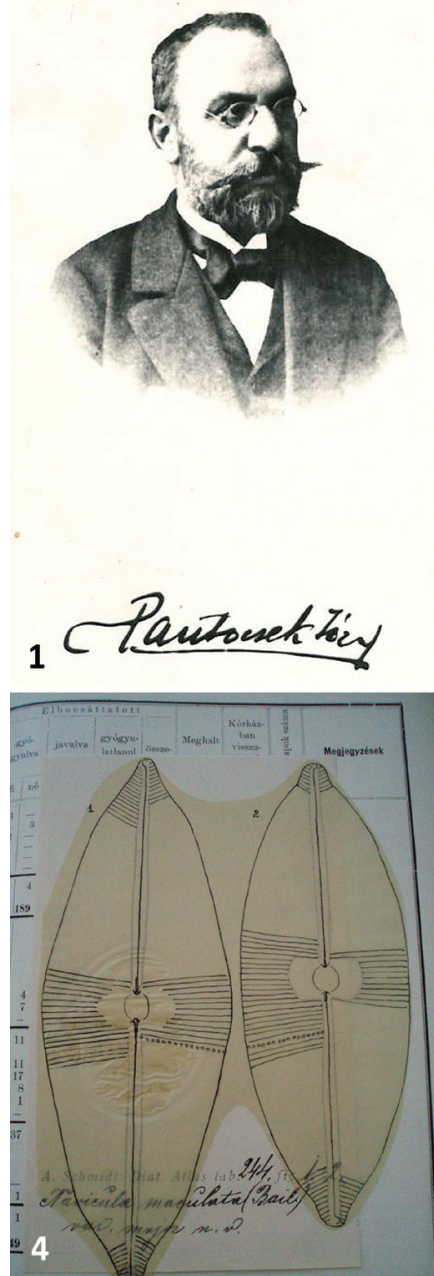
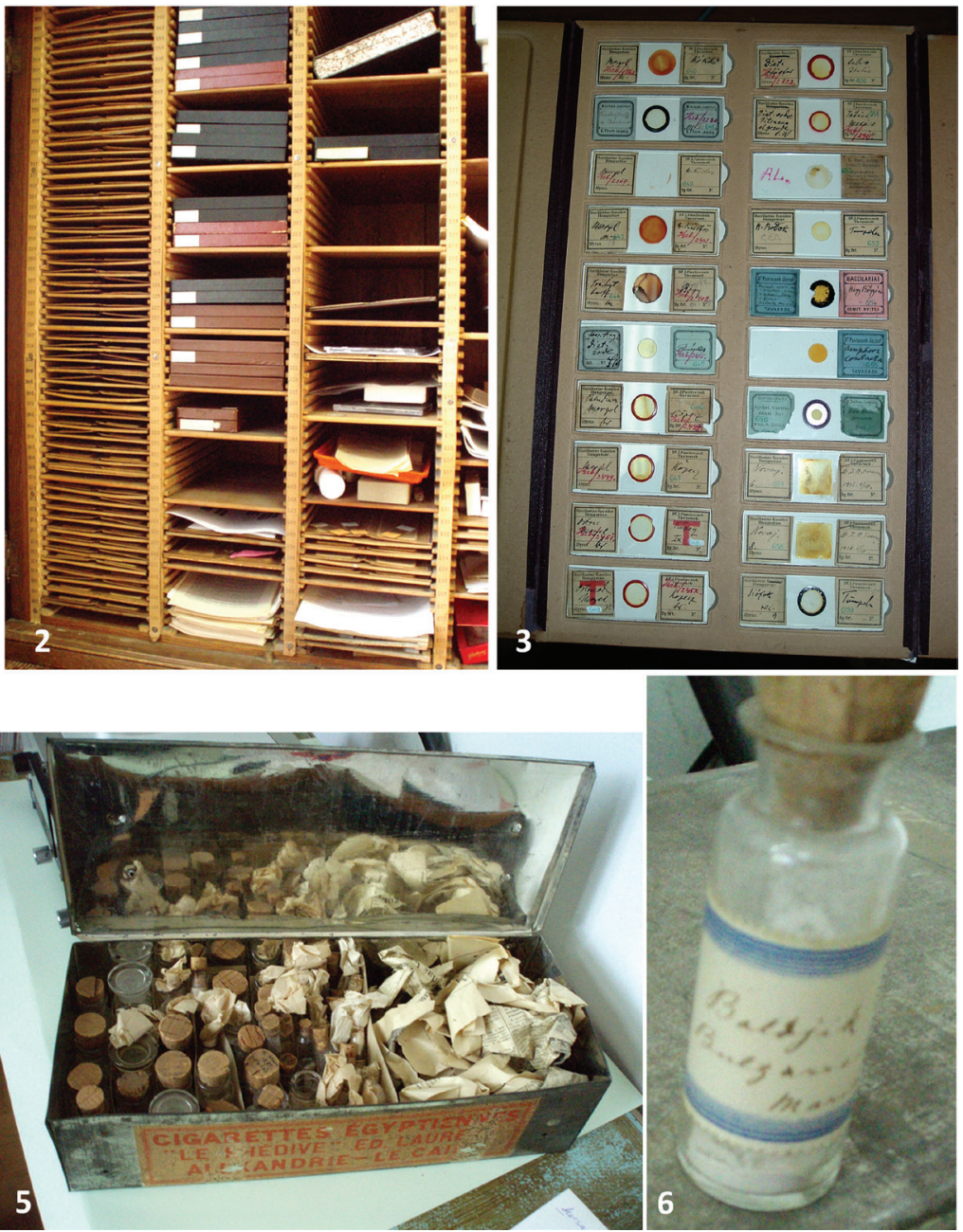


\section{RESULTS AND DISCUSSION}

Ten characteristic diatom species of regional and local importance were selected in the examined material. Apart from the list given below, several other siliceous microfossils were present in the studied samples, e.g., ebridean (Fig. 3.5). The morphological variability of the identified taxa, coupled with photographic documentation by SEM and short taxonomical descriptions, are given herein.

\section{Taxonomic notes}

\section{Actinocyclus octonarius Ehrenberg, 1838}

(Figs. 2.5-6)

1838. Actinocyclus octonarius Ehrenberg, p. 172, P1. 21, Fig. 7. 1861. Actinocyclus ehrenbergii Ralfs in Pritchard, p. 834.

Description. Valvae circular, flat or shallowly convex, with a broadly raised margin. Valvae centre small, irregular, often filled with scattered puncta. Diameter $45.5 \mu \mathrm{m}$. Areolae round, in radial rows, 14 in $10 \mu \mathrm{m}$. Areolae rows grouped in broad fascicles set off by continuous rows. Valve mantle finely areolate (about 22-24 in $10 \mu \mathrm{m})$. Pseudonodule large, well-defined, annulateoperculate, located on the edge of the valve face.

Stratigraphic and geographic distribution. This species is present in the Sarmatian deposits in the VarnaBalchik depression (Kozyrenko, Temniskova-Topalova, 1990; Temniskova-Topalova, 1994), cosmopolitan, common in modern brackish-marine coastal areas.

\section{Actinocyclus podolicus (Missuna) Kozyrenko, 1959 (Figs. 2.1-4)}

1913. Aulacodiscus beringensis Mann var. podolicus Missuna, p. 11, Fig. 53.

1913. Aulacodiscus beringensis Mann var. molokischianus Missuna, p. 11, Fig. 51.

1959. Actinocyclus (?) podolicus Kozyrenko, P1. 1, Fig. 4.

2003. Actinostephanos podolicus (Missuna) Kozyrenko, p. 126, Figs. 1-8.

2008. Actinostephanos podolicus (Missuna) Kozyrenko, p. 33, P1. 46, Figs. 1-10.

Description. Valvae circular, nearly flat with slightly raised centre. Diameter ranging between $35 \mu \mathrm{m}$ and $57 \mu \mathrm{m}$. Areolae about $15-17$ in $10 \mu \mathrm{m}$, small, round, arranged in subparallel to radial rows. Areolae rows grouped into fascicles set off by continuous subparallel rows. Hyaline stripes mark the areolae fascicles on the valve face (one in $10 \mu \mathrm{m}$ ). Valvae centre is small, irregular hyaline area. Valvae mantle finely areolate (about 20 in $10 \mu \mathrm{m}$ ). Pseudonodule of medium size, easily visible between the hyaline stripes. Labiatae processes not observed.

Notes. Actinocyclus podolicus was introduced as a variety of Aulacodiscus beringensis Mann var. podolicus Missuna by Missuna (1913). She described two varieties within Aulacosidiscus berginensis Mann in the materials from the area of Molokish (Crimean Peninsula, former USSR). The main differences between these two varieties are the valvae dimensions, which are larger in Aulacodiscus beringensis Mann var. molokischianus Missuna, the pattern of fasciculation, as well as the number of the hyaline stripes in $10 \mu \mathrm{m}$, the number of the areolae rows in $10 \mu \mathrm{m}$, and the form of the central area. Kozyrenko (1959) combined these two varieties within the genus Actinocyclus Ehr. as Actinocyclus (?) podolicus Koz. After revision and SEM investigations, Kozyrenko (2003) placed this taxon in the genus Actinostephanos Khursevich due to the lack of pseudonodule, which is the main morphological difference between the genera Actinocyclus Ehr. and Actinostephanos Khursevich. The illustrations in her publication (Kozyrenko, 2003, Figs. 1-8), based on her own collections from the Crimean Peninsula, included forms very similar only to Aulacodiscus beringensis Mann var. molokischianus Miss. (Missuna, 1913, Fig. 51). The new LM illustration was included in the last publication of Kozyrenko in Strelnikova (2008, Pl. 46, Fig. 1), which is very similar to the figure of Missuna (1913, Fig. 51) of Aulacodiscus beringensis Mann var. podolicus Missuna. Our specimens are very similar to this illustration. Most importantly, in these specimens, the structures of the pseudonodule are visible, which is one of the most important morphological features of Actinocyclus Ehr. (Round et al., 1990). Our detailed examination of the fine structure supports its placement in the genus Actinocyclus Ehr. - as Actinocyclus podolicus (Missuna) Kozyrenko. Reexamination of the original material is urgently needed, however, before its taxonomic affinities can be assessed. Stratigraphic and geographic distribution. The species is present in the Middle Sarmatian (Bessarabian) deposits in the Varna-Balchik depression (Kozyrenko, Temniskova-Topalova, 1990; Temniskova-Topalova, 1994).

Fig. 1. Original Dr J. Pantocsek materials and micas from the J. Pantocsek Collection hosted in the Natural History Museum, Budapest.

1. Dr Jozef Pantocsek (1846-1916).

2, 3. Original micas and slides from the J. Pantocsek Collection.

4. Pantocsek's original drawings.

5. Raw materials.

6. Raw material - diatomaceous earth from Balchik (NE Bulgaria). 

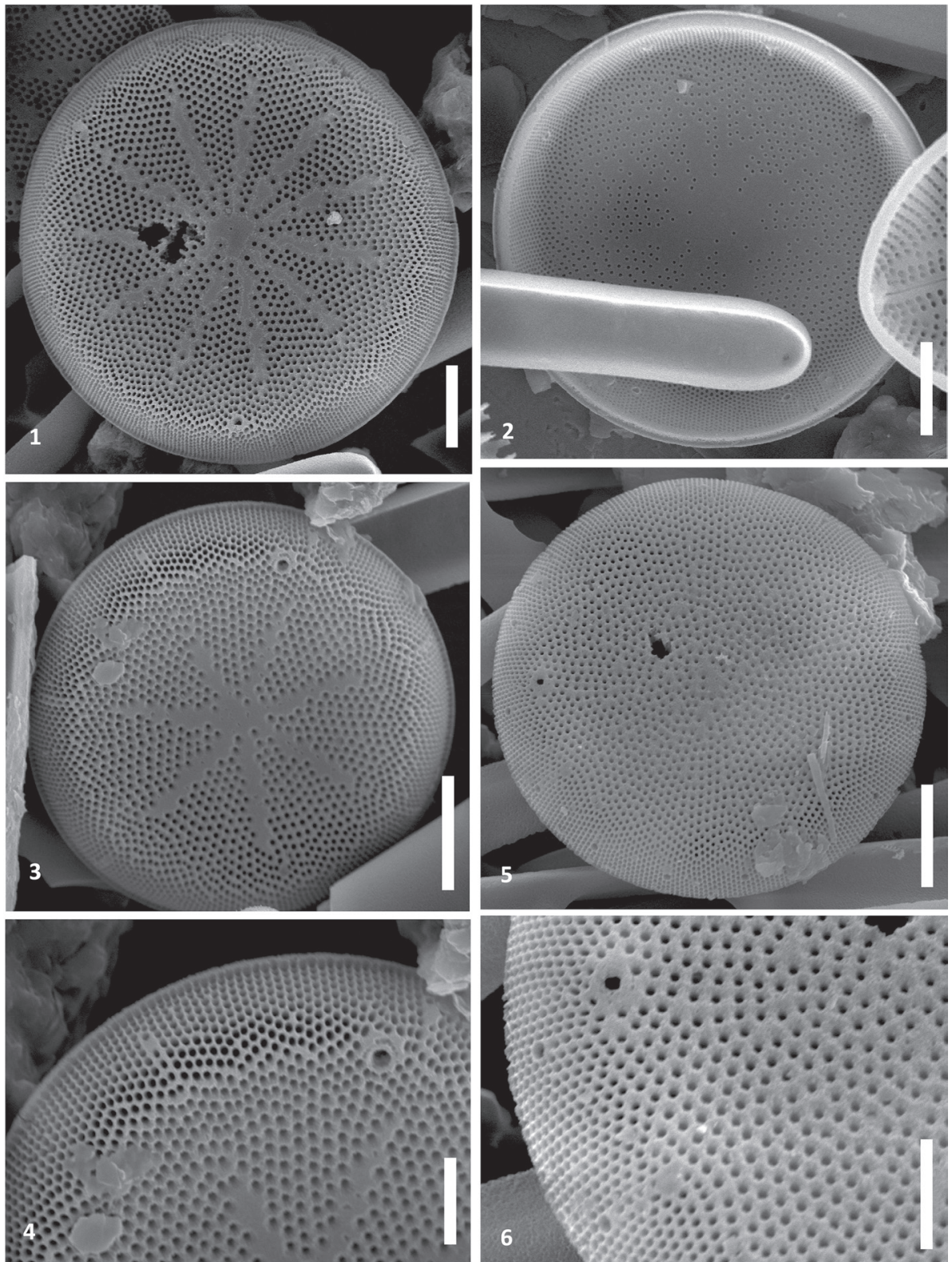

Fig. 2. Species of the genus Actinocyclus Ehrenberg.

1-4. Actinocyclus podolicus (Missuna) Kozyrenko. 1-3) External valve view. Note the position of the hyaline strips and the place and form of the pseudonodule; 4) Internal view with position of the pseudonodule.

5-6. Actinocyclus octonarius Ehrenberg - external valve view. 6) External view of annulate pseudonodule and exit of the labiatae processes.

Scale bars $=5 \mu \mathrm{m}(4,6) ; 10 \mu \mathrm{m}(1-3,5)$.

Caloneis sectilis (A.S.) Cl. var. boryana (Pantocsek) Cleve, 1894

(Fig. 3.4)

1894 Caloneis sectilis (A.S.) Cl. var. boryana (Pantocsek) Cleve, p. 60.

1889 Navicula boryana Pantocsek, Pl. 28, Fig. 407.

Description. Valvae elongate to elongate-elliptical, with rounded apices, $120 \mu \mathrm{m}$ long, $27 \mu \mathrm{m}$ wide, with
8-9 striae in $10 \mu \mathrm{m}$. Raphe straight, axial area broadly lanceolate, widening towards the large round to elliptical central area. Straight markings on either side of the central nodule. Striae are almost parallel in the centre, radiate at the ends.

Stratigraphic and geographic distribution. The species is present in the Lower-Middle Sarmatian (VolhynianBessarabian) deposits in the Varna-Balchik depression (Kozyrenko, Temniskova-Topalova, 1990; TemniskovaTopalova, 1994). 

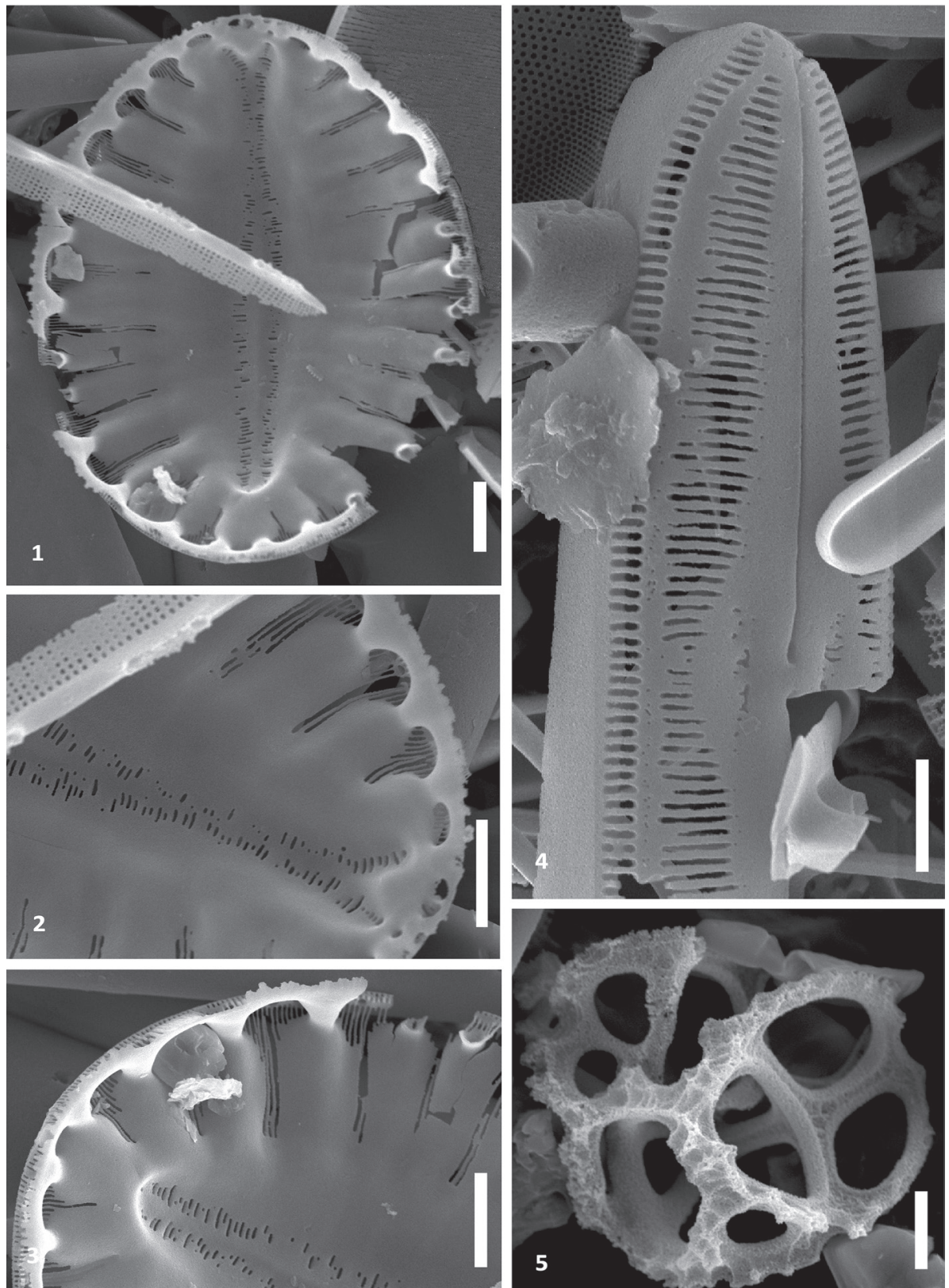

Fig. 3. 1-3. Surirella comis Schmidt, internal valve view.

4. Caloneis sectilis (A.S.) Cl. var. boryana (Pantocsek) Cleve.

5. Ebridian.

Scale bars $=5 \mu \mathrm{m}(5) ; 10 \mu \mathrm{m}(1-4)$.

\section{Campylodiscus limbatus var. astralis Eulenstein, 1875} (Fig. 4.1)

1875. Campylodiscus limbatus var. astralis Eulenstein in Schmidt et al. (1874-1959), Pl. 17, Fig. 1.

Description. Valvae subcircular, weakly saddle-shaped, $200 \mu \mathrm{m}$ in diameter, with a distinct, large central area. Marginal costae (five in $10 \mu \mathrm{m}$ ) extending over one-third of the valve radius. Median area of valve large, hyaline, with elliptical form, crossed by one striated ridge.
Stratigraphic and geographic distribution. The species is present in the Lower-Middle Sarmatian (VolhynianBessarabian) deposits in the Varna-Balchik depression (Kozyrenko, Temniskova-Topalova, 1990; TemniskovaTopalova, 1994).

\section{Climacosphenia moniligera Ehrenberg, 1841}

(Fig. 5.4)

1841. Climacosphenia moniligera Ehrenberg, (1843), p. 411, Pl. 2, Fig. 6: 1. 

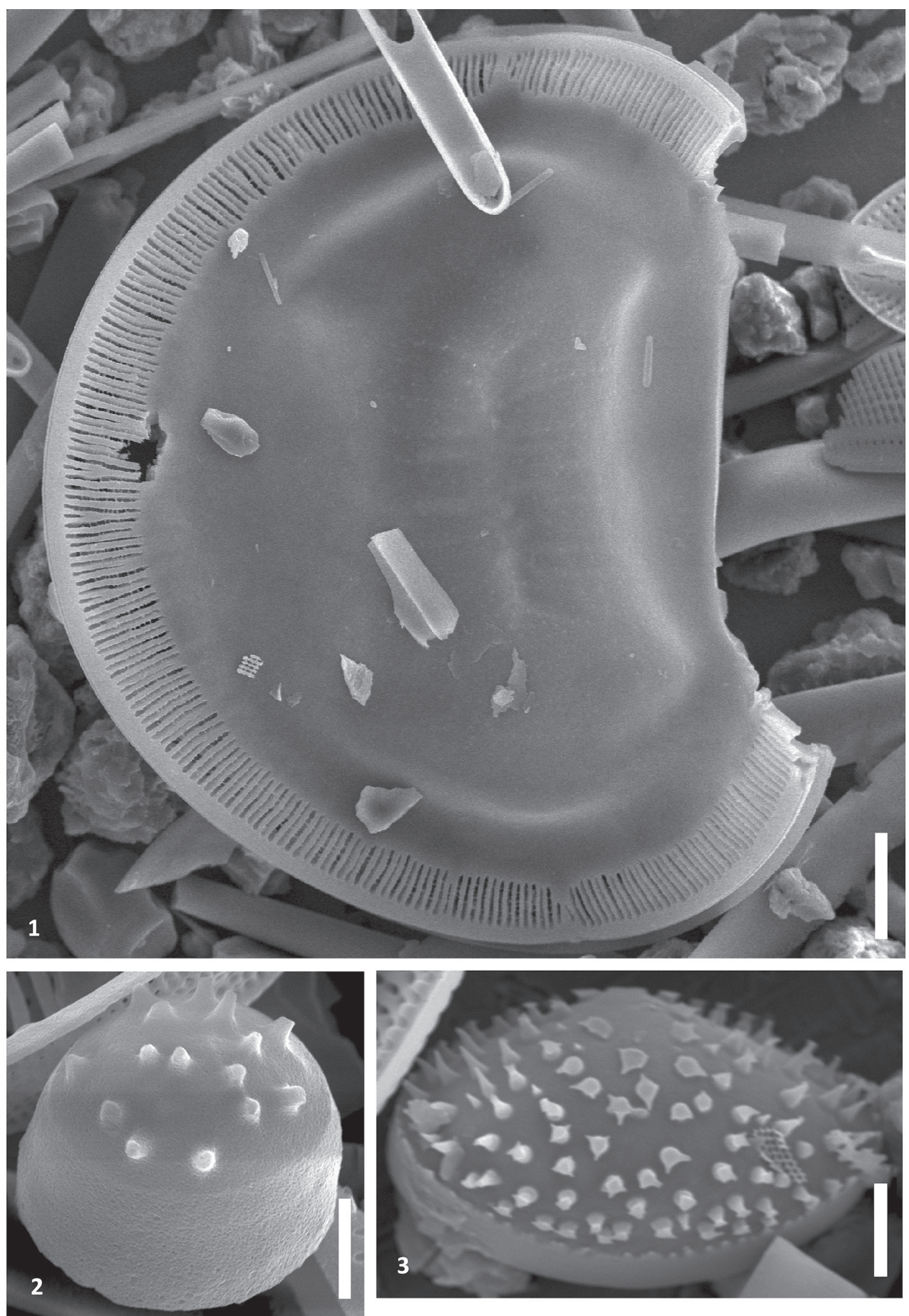

Fig. 4. Campylodiscus limbatus var. astralis Eulenstein (1), and resting spores of Chaetoceros (2-3). Scale bars $=5 \mu \mathrm{m}(2-3) ; 20 \mu \mathrm{m}(1)$.

Description. Frustules in girdle view wedge-shaped with straight margins. Intercalary bands with numerous septa. Valvae heteropolar, club-shaped with rounded apices, gradually narrowing towards the foot-pole; more than $400 \mu \mathrm{m}$ long (broken frustules), $22 \mu \mathrm{m}$ wide (in the widest part). Sternum absent, transapical striae above the foot pole, 13-15 in $10 \mu \mathrm{m}$. Cingulum composed of a fimbriate volvocopula bearing transverse septa and two copulae.
The septa are solid, with complete bars towards the headpole and finger-like joints towards the base-pole.

Stratigraphic and geographic distribution. The species is present in the Lower-Middle Sarmatian (VolhynianBessarabian) deposits in the Varna-Balchik depression (Kozyrenko, Temniskova-Topalova, 1990; TemniskovaTopalova, 1994), common in modern brackish-marine coastal areas. 

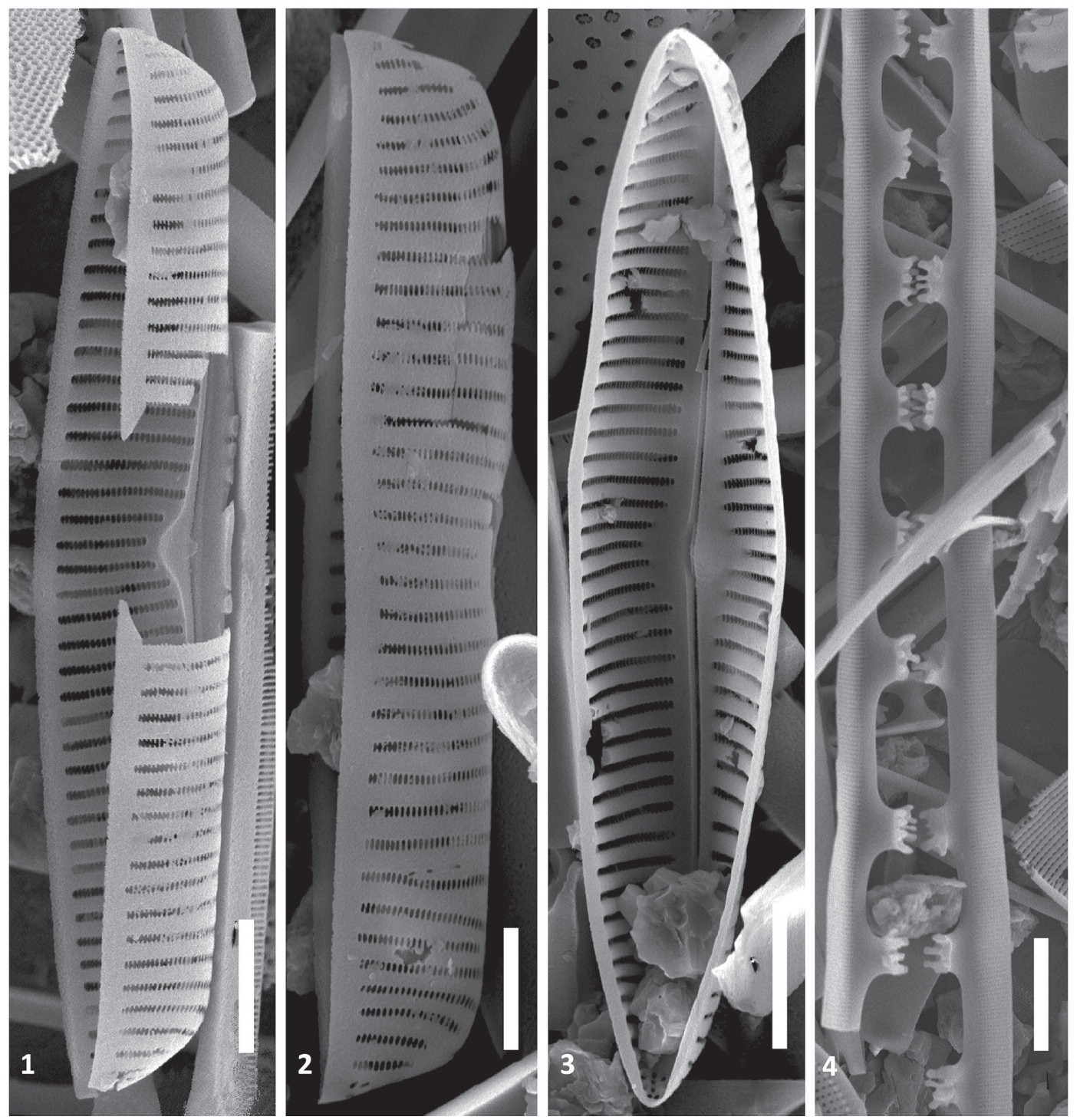

Fig. 5. Navicula cancellata Donkin (1-3), and Climacosphenia moniligera Ehrenberg (4).

Scale bars $=10 \mu \mathrm{m}(1-3) ; 20 \mu \mathrm{m}(4)$.

\section{Grammatophora insignis var. doljensis Grunow, 1886} (Figs. 6.1-5)

1886. Grammatophora insignis var. doljensis Grunow in Pantocsek, p. 38, Pl. 26, Fig. 238.

Description. Frustules rectangular to square in girdle view, elliptical in valve view, with slightly convex sides. Valvae are 108-133 $\mu \mathrm{m}$ long, 12.5-18.0 $\mu \mathrm{m}$ wide. Striae density: 22 in $10 \mu \mathrm{m}$. Striae distinctly punctuate, uniseriate, arranged in parallel rows. Sternum very narrow, linear. Each apex is occupied by an apical pore field. Slightly undulate septa are distinctive in girdle view, with a characteristic elliptic opening in the centre. The presence of a rimoportula is distinguishable.
Stratigraphic and geographic distribution. The species is present in the Lower-Middle Sarmatian (VolhynianBessarabian) deposits in the Varna-Balchik depression (Kozyrenko, Temniskova-Topalova, 1990; TemniskovaTopalova, 1994).

\section{Navicula cancellata Donkin, 1872}

(Figs. 5.1-3)

1872. Navicula cancellata Donkin (1873), p. 55, P1. 8, Fig. 4.

Description. Valvae linear-lanceolate, with almost parallel sides and cuneate, sub-acute apices. Valve dimensions: length $65-75 \mu \mathrm{m}$, width $15.5 \mu \mathrm{m}$. Axial area linear, narrow; central area small, rounded, assy- 

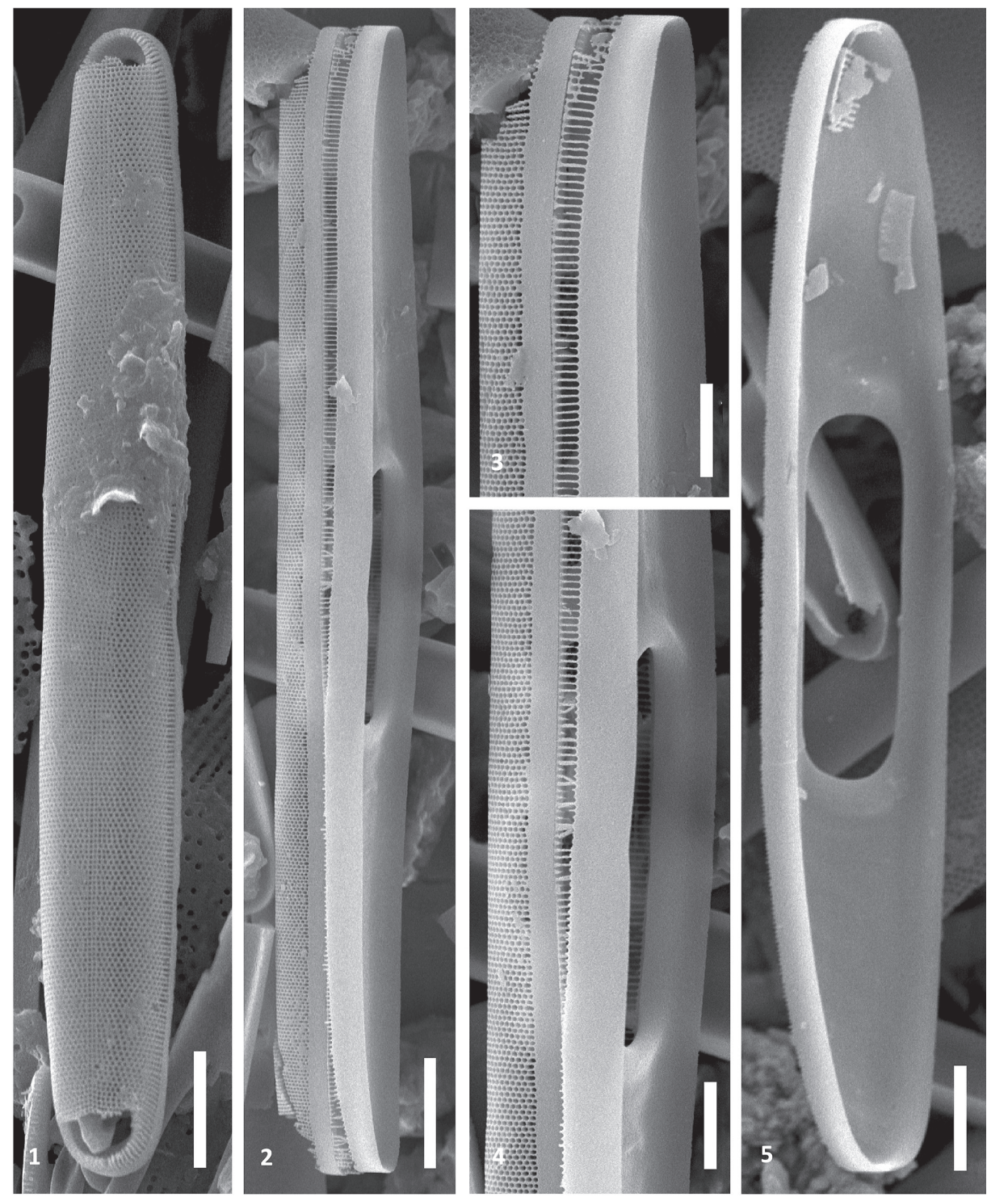

Fig. 6. Grammatophora insignis var. doljensis Grunow.

1. External view.

$2-4$. Tilted view of the frustule.

5. Septa.

Scale bars $=5 \mu \mathrm{m}(3-4) ; 10 \mu \mathrm{m}(1-2,5)$.

metrical. Raphe branches distinctly lateral. Internally, raphe slit is very narrow. Proximally simple raphe ends straight, located on a small central nodule. Distal-raphe endings terminating in twisted helictoglossae surrounded by hyaline area. Valve surface convex, striae coarse, weakly radiate in the middle, convergent towards the apices. Striae finely lineate, five in $10 \mu \mathrm{m}$.

Stratigraphic and geographic distribution. The species is present in the Middle-Upper Sarmatian (BessarabianKhersonian) deposits in the Varna-Balchik depression (Kozyrenko, Temniskova-Topalova, 1990; TemniskovaTopalova, 1994), common in modern brackish-marine coastal areas.

\section{Podosira loczyi Pantocsek, 1903}

(Figs. 7.1-6)

1903. Podosira loczyi Pantocsek, p. 82, Pl. 10, Figs. 172-173.

Description. Valvae hemispherical, no distinct valve mantle. Diameter ranging from $35 \mu \mathrm{m}$ to $40 \mu \mathrm{m}$, pervalvar axis $25-30 \mu \mathrm{m}$. Valve surface finely areolate; areolae loculate, arranged in decussate rows, about 20 in $10 \mu \mathrm{m}$. Rimoportulae are scattered over the whole valve. Outside, they have simple opening; inside, they are small oval structures without stalks.

Stratigraphic and geographic distribution. The species is present in the Lower-Middle Sarmatian (Volhynian- 

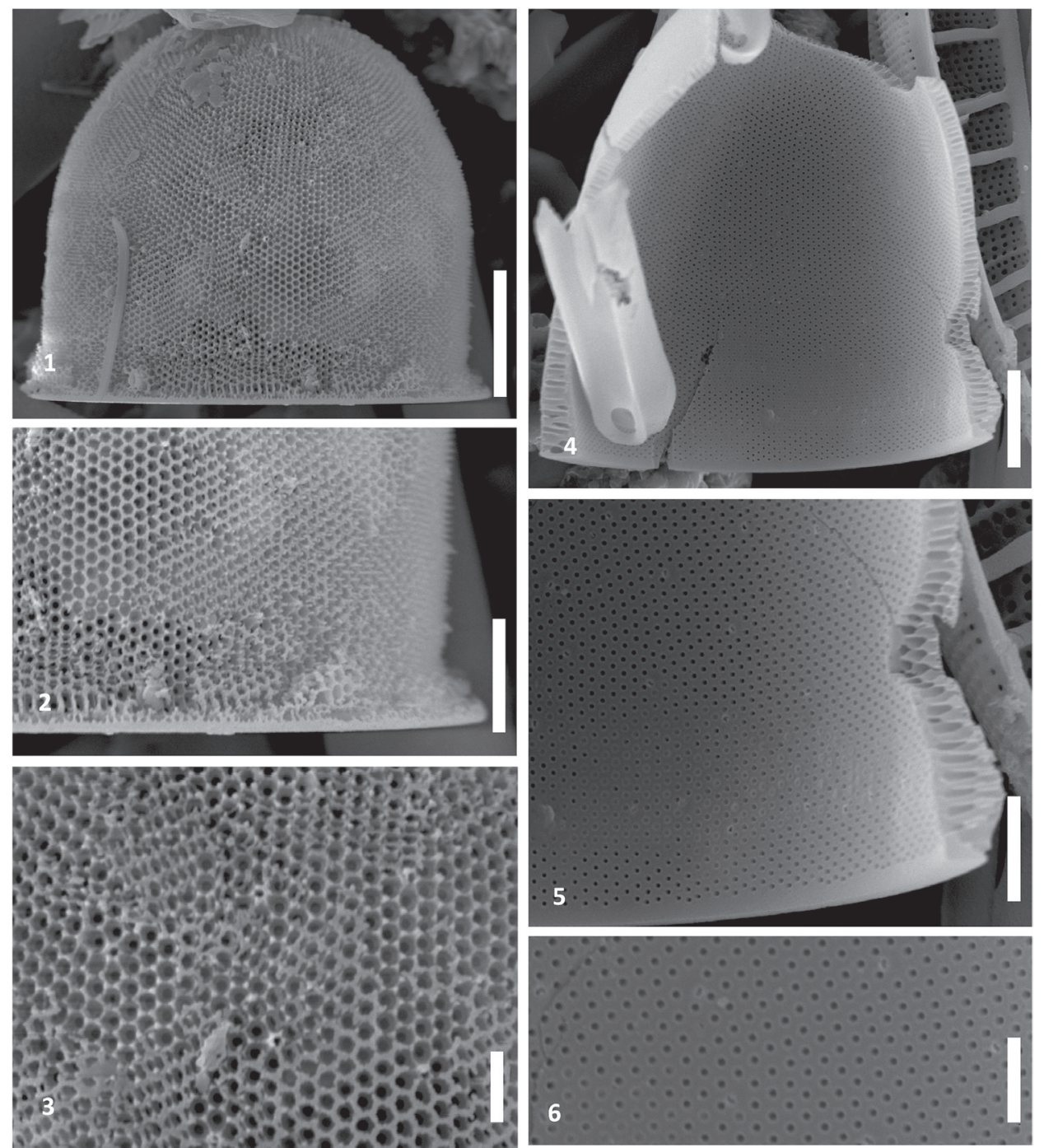

Fig. 7. Podosira lozyi Pantocsek.

1-3. Podosira lozyi Pantocsek. External valve view, decussate rows of areolae, simple opening of the rimoportule. 4-6. Podosira lozyi Pantocsek. Internal valve view, small oval structures of the rimoporule without stalks.

Scale bars $=2 \mu \mathrm{m}(3) ; 5 \mu \mathrm{m}(2,5-6) ; 10 \mu \mathrm{m}(1,4)$.

Bessarabian) deposits of the Varna-Balchik depression (Kozyrenko, Temniskova-Topalova, 1990; TemniskovaTopalova, 1994).

\section{Surirella baldjickii Norman, 1861}

(Figs. 8.1-4)

\section{Surirella baldjickii Norman, p. 6, Pl. 2, Fig. 2.}

Description. Valvae strongly silicified, bipolar, panduriform, with broadly rounded apices; length $100-150 \mu \mathrm{m}$, width $44-58 \mu \mathrm{m}$. Margins strongly constructed in the middle. Central area broadly lanceolate. The valve surface striated, striae multiseriate, containing very small round poroids $(16-18$ in $10 \mu \mathrm{m})$. Raphe system running around the whole perimeter of the valve face.

Stratigraphic and geographic distribution. The species is present in the Lower-Middle Sarmatian (Volhynian-
Bessarabian) deposits of the Varna-Balchik depression (Kozyrenko, Temniskova-Topalova, 1990; TemniskovaTopalova, 1994).

\section{Surirella comis Schmidt, 1874}

(Figs. 3.1-3)

1874. Surirella comis Schmidt, Pl. 4, Figs. 3-7.

Description. Valvae broadly elliptical, with almost equal ends, $95 \mu \mathrm{m}$ long, $75 \mu \mathrm{m}$ broad. Marginal costae short, $1.5-2$ in $10 \mu \mathrm{m}$. Central area oval, the axial area enclosed by two longitudinal bands of short striae, which do not reach the ends of the valve.

Stratigraphic and geographic distribution. Probably warm-water species (Hendey, 1964), until now unknown from the Sarmatian deposits in the Varna-Balchik depression. 

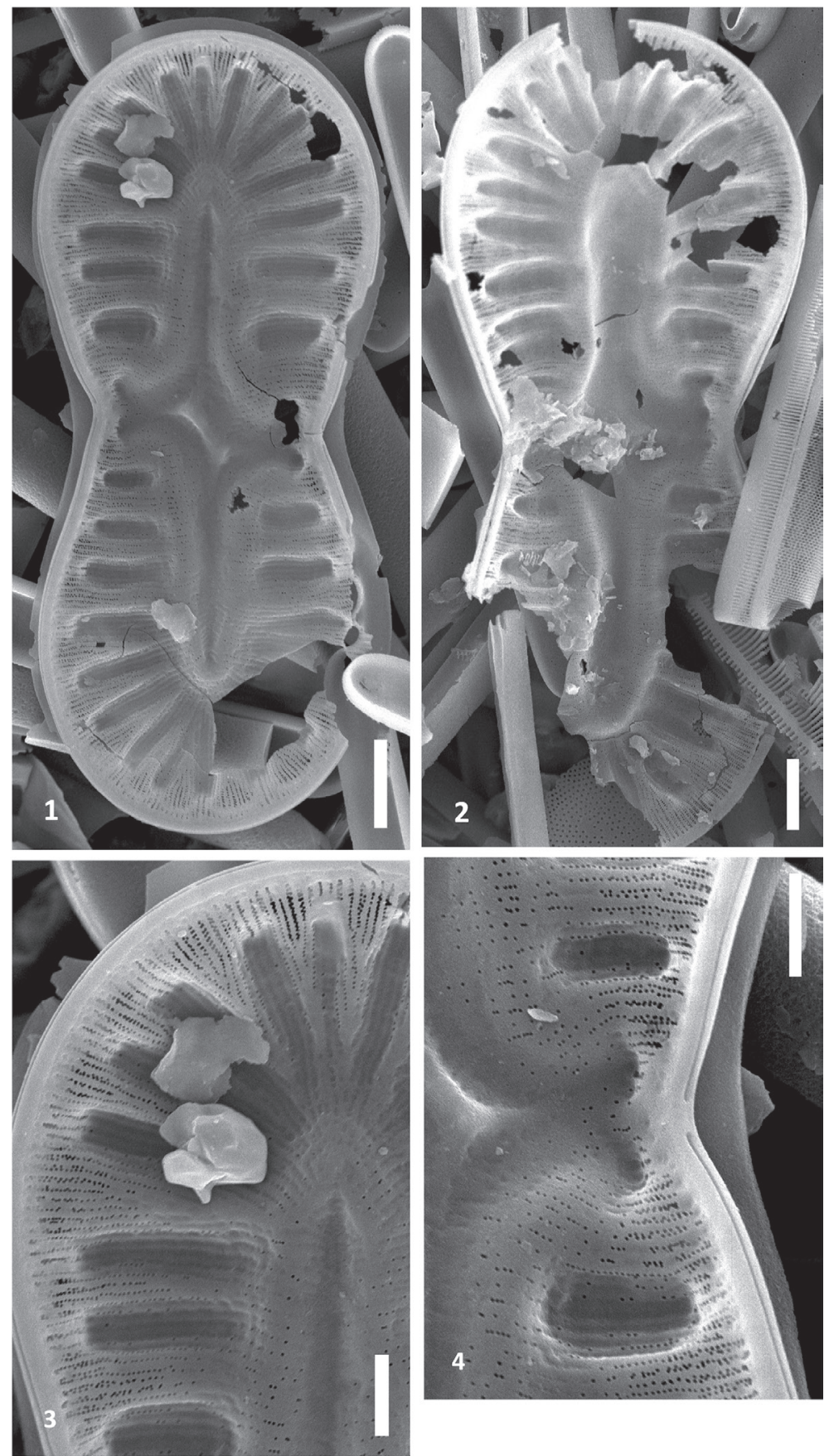

Fig. 8. Surirella baldjickii Norman. 1-2. Internal view. 3-4. Details. Scale bars $=5 \mu \mathrm{m}(3-4) ; 10 \mu \mathrm{m}(1-2)$.

\section{CONCLUDING REMARKS}

In the examined material, ten characteristic diatom species of regional and local importance were selected. Comparisons with previous diatom finds (Kozyrenko, Temniskova-Topalova, 1990; Temniskova-Topalova, 1994) show that the majority of them have already been report-

ed from the Sarmatian deposits of the Varna-Balchik depression. Herein, the presence of Surirella comis Schmidt has been recognized for the first time from Bulgaria, as either fossil or recent form.

In the present investigation of the Balchik diatomites, housed in the Pantocsek Collection, species characteristic for the association of the Achnathes baldjikii var. 
podolica Subzone have been indicated: Actinocyclus podolicus (Missuna) Kozyrenko, Caloneis sectilis (A.S.) Cl. var. boryana (Pantocsek) Cleve, Campylodiscus limbatus var. astralis Eulenstein, Grammatophora insignis var. doljensis Grunow, Podosira loczyi Pantocsek and Surirella baldjickii Norman. Its stratigraphic range is within the Sarmatian Stage (Bessarabian Substage).

\section{Acknowledgements}

This research was supported by the Synthesys award HU-TAF-3690, the Hungarian Natural History Museum (Budapest), Project FP 6 (Structuring the European Research Area Programme, http://www.synthesys.info/) to Nadja Ognjanova-Rumenova.

\section{REFERENCES}

Anonymous. 1975. Proposal for a standardization of diatom morphology and diagnoses. Nova Hedwigia Beiheft 53, 323-354

Brightwell, T. 1859. On some of the rarer or undescribed species of Diatomaceae. Part I. Quarterly Journal of Microscopical Sciences 7, 179-181.

Cleve, P.T. 1894. Synopsis of the naviculoid diatoms. Part I. Kongiliga Svenska Vetenskaps-Akademiens Handlinger 26 (2), 1-194

Cleve, P.T. 1895. Synopsis of the naviculoid diatoms. Part II. Kongiliga Svenska Vetenskaps-Akademiens Handlinger 27 (3), 1-219.

Donkin, A.S. 1873. The natural history of the British Diatomaceae. Part III. London: John Van Voorst, 1 Paternoster Row, pp. 49-74, pls 9-12.

Droop, S. 1998. Diploneis sejuncta (Bacillariophyta) and some new species from an ancient lineage. Phycologia 37 (5), 340-356.

Ehrenberg, C.G. 1838. Die Infusionsthierchen als vollkommene Organismen. Leipzig. Leopold Voss., i-xviii, 548 pp.

Ehrenberg, C.G. 1843. Verbreitung und Einfluss des mikroskopischen Lebens in Süd- und Nord-Amerika. Abhandlungen der Königlichen Akademie der Wissenschaften zu Berlin $1841,291-466$.

Grunow, A. 1862. Die Österreichischen Diatomeen nebst Anschluss einiger neuen Arten von anderen Lokalitäten und einer kritischen Übersicht der bisher bekannten Gattungen und Arten. I. Epithemiaceae, Meridioneae, Diatomeae, Entophyleae, Surirelleae, Amphipleureae. Verhandlungen der kaiserlich-königlichen zoologisch-botanischen Gesellschaft in Wien 12, 315-472.

Grunow, A. 1880. Bemerkungen zu den Diatomeen von Finmark, dem Karischen Meere und von Jenissey nebst Vorarbeiten fur Monographien der Gattungen Nitzschia, Achnanthes, Pleurosigma, Amphiprora, Plagiotropis, Hyalodiscus, Podosira und einiger Navicula-Gruppen. Kongliga Svenska Vetenskaps-Akademiens Handlingar 17 (2), 16-121.

Grunow, A. 1886. Texte zu Van Heurck, H. Types de Synopsis des Diatomées de Belgique. Ser. V-XXII, Determination, Notes et Diagnoses par Grunow. Botanisches Centralblatt 33, 323-325.

Guiry, M., D., Guiry, G., M. 2016. AlgaeBase. World-wide electronic publication, National University of Ireland, Galway. http://www.algaebase.org; searched on 20 January 2016.

Hendey, N. I. 1964. An introductory account of the smaller algae of British coastal waters. V. Bacillariophyceae (Diatoms). H.M. Stationery Office, London, 317 pp.

Hustedt, F. 1927-1966. Die Kieselalgen Deutschlands, Osterreichs und der Schweiz. In: L.Rabenhorst: Kryptogamen-
Flora von Deutschland, Osterreich und der Schweiz 7 (2/5), 577-736.

Kojumdgieva, E., Popov, N. 1981. Régions structuro-paléogéographiques en Bulgarie du Nord-Ouest Pendant Le Néogène. Comptes rendus de l'Académie bulgare des Sciences 34 (9), 1273-1275.

Kozyrenko, T. 1959. Diatom flora from Upper Miocene sediments in the realm of Crimea. Vestnik Leningradskogo Universiteta, ser. Biologie 21, 51-61 (in Russian).

Kozyrenko, T. 2003. Morphology and taxonomy of Actinocyclus podolicus (Bacillariophyta) from Miocene sediments of Pontic-Caspian region. Botanical Journal 88 (11), 125-128 (in Russian).

Kozyrenko, T., Temniskova-Topalova, D. 1990. Correlation of diatoms from marine Upper Miocene sediments within the boundaries of Eastern Paratethys. In: Simola, H. (Ed.), Proceedings of the 10th International Diatom Symposium, Joensuu, Finland 1988, 249-256.

Levkov, Z. 2009. Amphora sensu lato. In: Lange-Bertalot, H. (Ed.), Diatoms of Europe 2. A.R.G. Gantner Verlag K.G., Ruggell., 916 pp.

Missuna, A. 1913. Beitrag zur Kenntnis der fossilen Diatomeen Südrusslands. Collection Rapports in Honour of $25^{\text {th }}$ Anniversary Prof. V.I. Vernadsky in Science, 138-173.

Norman, A. M. 1861. Contributions to British Carcinology. I. Characters of undescribed Podophthalmia and Entomostraca. The Annals and Magazine of Natural History 8 (3), 273-281.

Olshtynskaya, A. 2001. Miocene marine diatom biostratigraphy of the Eastern Paratethys (Ukraine). Geologica Carpathica $53(4), 173-181$.

Pantocsek, J. 1892. Beiträge zur Kenntniss der Fossilen Bacillarien Ungarns III. Süßwasser Bacillarien. Anhanganalysen 15 neuer Depots von Bulgarien, Japan, Mähren, Rußlands und Ungarn. Nagy-Tapolcsány, Buchdrucherei von Julius Platzko, 42 pls. (without text).

Pantocsek, J. 1886. Beiträge zur Kenntnis der Fossilen Bacillarien Ungarns I. Marine Bacillarien. Nagy-Tapolcsány, Buchdrucherei von Julius Platzko, 74 pp.

Pantocsek, J. 1889. Beiträge zur Kenntniss der Fossilen Bacillarien Ungarns. II. Brackwasser Bacillarien Anhang: Analyse de marine Depots von Bory, Bremia, Nagy-Kürtös in Ungarn; Ananio und Kusnetzk in Russland. NagyTapolcsány Buchdruckerei von Julius Platzko, 120 pp.

Pantocsek, J. 1903. Beiträge zur Kenntnis der fossilen Bacillarien Ungarns. I. Marine Bacillarien. Verlag von W. Junk, Berlin, 76 pp., pls. 30 (without text.)

Pantocsek, J. 1905. Beiträge zur Kenntnis der fossilen Bacillarien Ungarns III. Beschreibung der auf abgebildeten Arten. Pozsony, Buchdruckerei C. F.Wigand, 118 pp. 
Popov, N., Kojumdgieva, E. 1987. The Miocene in northeastern Bulgaria (lithostratigraphic subdivision and geological evolution). Review of the Bulgarian Geological Society 48 (3), 15-33 (in Bulgarian).

Pritchard, A. 1861. History of Infusoria including the Desmidiaceae and Diatomaceae, British and Foreign. Wittaker \& Co., London, 968 pp.

Ross, R. 1963. The diatom genus Capartogramma and its identity of Schizostauron. Bulletin of the British Museum (Natural History), Botany 3, 49-92.

Ross, R., Cox, E., Karayeva, N., Mann, D., Paddock, T., Simonsen, R., Sims, P. 1979. An emended terminology for the siliceous component of the diatom cell. Nova Hedwigia Beiheft 64, 513-533.

Round, F., Crawford, R., Mann, D. 1990. The Diatoms. Biology and morphology of the genera. Cambridge University Press, Cambridge, 747 pp.

Schmidt, A. 1874-1959. Atlas der Diatomaceen-Kunde. 460 Tafeln. Aschersleben and Leipzig.
Strelnikova, N.I. (Ed.). 2008. Diatoms of Russia and adjacent countries, fossil and recent. Vol. II: Part 5. St. Petersburg university press, $170 \mathrm{pp}$. (in Russian).

Temniskova-Topalova, D. 1982. Sarmatian diatoms from the western parts of the Eastern Paratethys, Baltchik, NorthEastern Bulgaria. Acta Geologica Academiae Scientiarum Hungaricae 25 (1-2), 65-84.

Temniskova-Topalova, D. 1990. Biostratigraphical subdivision of the Miocene in northeastern Bulgaria by diatoms. In: Nikolov, T. (Ed.), Microfossils in Bulgarian stratigraphy. The Union of Scientific Workers in Bulgaria, 73-80 (in Russian).

Temniskova-Topalova, D. 1994. Miocene diatom florae in Bulgaria - structure, evolution, palaeoecology and biostratigraphy. DSc.Thesis, University of Sofia, 318 pp. (in Bulgarian).

Temniskova-Topalova, D., Economou-Amilli, A. 1989. Notes on Achnanthes baldjickii (Brightw.) Grun., an interesting fossil diatom from Bulgaria. Archiv für Hydrobiologie 82 (4), 487-495. 